\title{
The Glorious Martyrdom of the Cross. The Franciscans and the Japanese Persecutions of 1597
}

\author{
Hélène Vu Thanh \\ Université de Bretagne-Sud - Département d'histoire. 4 rue Jean Zay - 56321 Lorient Cedex, France \\ e-mail: helenevuthanh@gmail.com \\ ORCID iD: http://orcid.org/0000-0002-6690-6214
}

Submitted: 10 October 2016. Accepted: 24 February 2017

\begin{abstract}
The Franciscan martyrdom of 1597 was not an unprecedented event in the young history of Japanese Christianity, as a first wave of persecutions occurred ten years earlier. But the echo it found in Asia, America and Europe, was unparalleled. This article aims to account for Franciscan success in giving worldwide publicity to what could otherwise be seen as a local event of limited consequence. The martyrdom of 1597 finds it roots in a context of tensions between Christians and Buddhists, who formed an overwhelming majority in Japan. However, the persecutions had more to do with the suppression of troubles than with theological considerations. But this political aspect is hardly apparent in Franciscan sources, which were mostly concerned with describing the martyrdom. From the start, the Franciscans were keen to actively circulate witnesses' accounts of the martyrdom in Mexico and in Europe. What also helped the event achieve worldwide publicity was that the Franciscans blamed the Jesuits for the outbreak of persecutions. The martyrdom indeed became the object of a dispute between religious orders, but with political ramifications, as the Spanish in the Philippines supported the Franciscans while the Jesuits were closely dependent on the Portuguese in Macao.
\end{abstract}

KEYWORDS: Franciscans; Jesuits; Japan; Martyr; Missionary; Sainthood.

Citation / Cómo citar este artículo: Vu Thanh, Hélène (2017) "The Glorious Martyrdom of the Cross. The Franciscans and the Japanese Persecutions of 1597". Culture \& History Digital Journal, 6 (1): e005. doi: http://dx.doi.org/10.3989/ chdj.2017.005.

RESUMEN: El glorioso martirio de la Cruz. Los Franciscanos y las persecuciones japonesas de 1597.- El martirio franciscano de 1597 no resultó un evento sin precedentes en la joven historia del cristiano japonés, ya que la primera ola de persecuciones se había producido ya diez años antes. Sin embargo, este evento encontró un eco sin precedentes en Asia, América y Europa. Este artículo analiza la forma en la que los franciscanos consiguieron hacer una campaña mundial de publicidad a partir de eventos locales que, de otra forma, hubieran sido de relevancia limitada. El martirio de 1597 tiene sus raíces en una tensión entre cristianos y budistas, quienes representaban una mayoría religiosa aplastante en Japón. Sin embargo, la persecución está principalmente relacionada con un deseo de eliminar altercados y no con cuestiones teológicas. Sin embargo, la dimensión política apenas aparece en las fuentes franciscanas, que se concentran sobre todo en la descripción del martirio. Desde el principio, los franciscanos circularon con mucho éxito los testimonios de los testigos por Nueva España y Europa. También contribuyó a su éxito publicitario mundial que los franciscanos culparan a los jesuitas del estallido de las persecuciones. El martirio japonés se convirtió así en objeto de disputa entre las dos órdenes religiosas, con ramificaciones políticas considerables, ya que los franciscanos dependieron en los hispanos de las Filipinas y los jesuitas en el Macao portugués.

PALABRAS CLAVE: Franciscanos; Jesuitas; Japón; Mártires; Misioneros; Santidad.

Copyright: (C) 2017 CSIC. This is an open-access article distributed under the terms of the Creative Commons Attribution License (CC BY) Spain 3.0. 
In his account of the Franciscan missions to Asia, chronicler Marcelo de Ribadeneira lauded the "glorious martyrdom of the Cross" that six Franciscans had just suffered in Nagasaki. ${ }^{1}$ Through this particular case, this article deals with the economy of anti-Christian religious violence in the context of overseas missions. More specifically, it examines the strategies developed by missionaries in order to capitalize on the persecution they underwent.

This famous episode immediately received considerable attention around the Christian world, publicized as it was by the Franciscans themselves. ${ }^{2}$ Martyrdom was not a rare theme in the European context of Catholic-Protestant conflicts or in the Americas. But Asia, let alone Japan, had provided few examples. In fact, since the beginning of the Jesuit mission in 1549, the Japanese had been constructed in missionary discourse as a refined people, receptive to Christianity and eager to convert (Bourdon, 1993). Outwardly, the outbreak of persecutions thus came unexpected, although the largely ineffective 1587 ban on Christianity represented a first warning. This was, however, a period of intense political change in Japan, as the long era of fragmentation and civil wars was coming to an end and a new centralized state was emerging (Hall, 1991: 40-95). It was in this context that the Franciscans in the Philippines took the initiative of establishing their own mission in Japan. They were thus faced from the start with a difficult political environment and with the hostility of the Portuguesesupported Jesuits, who deeply resented the religious and commercial competition the Spanish Franciscans represented ( Vu Thanh, 2014). Yet the violence that flared in 1597 came to them as a shock, and the reaction was to blame the putative instability of the "tyrant", Toyotomi Hideyoshi, then Japan's strongman.

The first item that this article addresses is the actual causes of the event, which have not been critically examined by historians. It must be said that the Franciscan mission to Japan itself has not been submitted to much scrutiny, and even less as an object in its own right. Arriving later and in much smaller numbers, the Franciscans are often treated as a minor phenomenon whose only interest is to put the Jesuit mission into perspective. As for the events of 1597 themselves, there has been a tendency to follow either the hagiographic Franciscan account or the deeply hostile perspective of their Jesuit rivals (Boxer, 1951: 137-187). While the representation of the martyrdom is analyzed here, this article is particularly concerned with rendering the complexity and the many implications of the event. First, this requires making sense of the roles and positions of the various actors (Jesuits, Franciscans, and the Japanese authorities) in what was actually a predictable drama. The article then proceeds with a comparison of the strategies (discursive, but not only) that the two orders deployed in order to impose their conflicting points of view on the incident. As we shall see, the written representations of the martyrdom which are scrutinized here, namely the accounts by two Franciscan friars who escaped arrest, Marcelo de Ribadeneira and Jerónimo de Jesús, are also strongly polemical works (Brockey, 2016). They aimed at supporting the
Franciscans in their struggle against the Jesuits, a struggle that also coincided, to a large extent, with the PortugueseSpanish rivalry in East Asia. The fact that Japan lied at the border of the two empires' spheres of influence was naturally a factor, but, more importantly, the island country represented a potential stepping stone for the conquest (whether military, spiritual or commercial) of China. The context of geopolitical tension explains how what could have gone down as a relatively minor event acquired world-wide notoriety.

\section{THE ROOTS OF THE MARTYRDOM: PAGAN PERSECUTION OR MISSIONARY MISDEED?}

\section{The role played by the Japanese authorities}

As St. Augustine phrased it, "Martyrem non facit poena, sed causa" - It is not the punishment but the cause that makes the martyr. The chroniclers were expected to address the reasons that had led the Japanese authorities to execute their brethren, providing explanations compatible with the claim to martyrdom. A difficulty was that Hideyoshi had warmly welcomed the establishment of the first Franciscans in the 1590s, even granting them a plot of land in the capital Miyako in addition to the official right to preach in the country (De Jesús, 1925: 98; Ribadeneira, 1599: 444). The Franciscans therefore blame the martyrdom of 1597 on a sudden mood swing on behalf of Hideyoshi, who is presented as an unstable and easily influenced "tyrant" (Ribadeneira 1599: 465) we shall see later whose influence is suspected. Meanwhile, the martyrs appear as the faultless victims of an arbitrary power which they did nothing to anger. Looking into the facts suggests a more complicated story. While it perhaps cannot be said that violence was looming large, there were several ominous signs.

First and foremost, the leader of Japan had taken previous measures against missionaries. In 1587, alarmed by the influence the Jesuits enjoyed over the converted daimyo (Japanese lords), and by their close links with Portuguese merchants, Hideyoshi had ordered the expulsion of the Society of Jesus as well as the destruction of several churches (Elison, 1988: 109). While the edict was but lightly enforced, it did entail an explicit warning to Christians. The Franciscans however had their own interpretation of the event: to them, Hideyoshi had decided to act against the Jesuits because of their inappropriate methods, but not out of hostility to the faith (Montilla, 1922: 477).

More importantly, and perhaps much less discernibly for the missionaries, the martyrdom of 1597 had precedents in the violent repression of another religious minority, the Ikkō. Hideyoshi's predecessor, Oda Nobunaga, had led a brutal campaign to eradicate the radical Buddhist sect, which he understood to be inherently inimical to the centralized state he hoped to build. ${ }^{3}$ The sect had enjoyed significant growth in the 1570s and its pontiff, the Honganji monshu Kōsa, had become a major daimyō in all but name, to the point that some Japanese historians see the 
Ikkō political structure as no less than a "religious monarchy" (Inoue cit. by Elison, 1988: 119). The sect was an obstacle to the unified political, social and economic order that Nobunaga sought to impose on the country. Numerous members of the sect who refused to submit were beheaded or crucified, while Nobunaga granted his protection to branches of the movement who accepted to take an oath of allegiance. The Franciscans may not have been as formidable a threat as the Ikkō, but they did represent a force which was apparently behaving more and more independently from the state. With the martyrdom, Hideyoshi resorted to the same kind of methods that had proven effective against the radical Buddhist sect.

Hideyoshi had been pleased with the arrival of the Franciscans, if only because he hoped to open diplomatic and commercial relations with the Spanish Philippines (Tremml, 2016). In addition, the mendicant order's evangelical intentions did not arouse his suspicion initially, as theses seemed mainly concerned with the bottom rungs of society, i.e. the poor and lepers. But the state soon found the Franciscans' action too conspicuous. Hideyoshi was irritated by reports of open-air preaching and of the missionaries' refusal to follow Japanese social customs. The disciples of St Francis indeed followed a very different strategy from that of the Jesuits. The latter adapted many aspects of their preaching, clothing and liturgy to local social and religious customs in order to facilitate the acceptance of Christianity. The edict of 1587 only reinforced their stance, as the Jesuits sought to keep a low profile and safeguard the mission going in spite of the official ban. The Franciscans had also from the start played an important diplomatic role ( $\mathrm{Vu}$ Thanh, 2015), acting as Manila's agents on many occasions (Gil, 1991). This dual role exposed them to suspicions of disloyalty.

And indeed it is above all the San Felipe incident that caused Hideyoshi to turn on the Franciscans. The galleon from the Philippines, laden with riches, ran aground on the shores of Tosa (Shikoku Island) in October 1596, and the local daimyō claimed its load for himself (Pérez, 1921b: 55). The Spanish captain decided to appeal to Hideyoshi to be allowed to return to the Philippines with his goods. He asked the Franciscans to intervene as translators and negotiators. But the Japanese leadership was greatly alarmed by the intrusion. Having in mind the precedents of the Spanish conquest of the Americas and of the Philippines, Hideyoshi accused the Franciscans of paving the way for an invasion thorough their evangelical activities, and sentenced them to death (Pérez, 1922a: 31 ). Yet the chroniclers, although they do mention the San Felipe incident, never present it at a significant factor for the martyrdom (Ribadeneira, 1599: 465; De Jesús, 1926: 405). Instead, they incriminate Hideyoshi's personality: he is depicted as a tyrant, easily influenced and prone to tantrums, who arbitrarily decides to put the missionaries to death. This serves two purposes. First, it allowed the chroniclers to mobilize the traditional archetype of the persecutors of the Church, as popularized since ancient times in particular by the work of Lactantius, On the Deaths of the Persecutors, as we shall see in more detail below. Second, by eliding the political background to the event, they likely aimed at shielding the martyrs' extra-religious activities from scrutiny, which could only have tarnished their image. The persecution is presented as an exceptional, unpredictable event, while it was arguably just another episode in the iterative violence orchestrated by an emerging but insecure state. However, the Franciscan hagiographies do identify a likely culprit for provoking Hideyoshi's sudden wrath.

\section{The Society of Jesus as the main culprit?}

The Franciscan chroniclers indeed quite explicitly blame the Society of Jesus. While ultimately they hold Hideyoshi responsible, they accuse the Jesuits of having done their best to undermine their presence in Japan before scheming for the Franciscans' arrest.

Relations between the two orders were notoriously tense in 1597, but had in fact been so ever since the first Franciscans landed in Japan, in 1584. The following year, the Jesuits started lobbying papal authorities for the enforcement of their monopoly on the Japanese mission, which was reasserted by the Ex pastoralis officio of Pope Gregory XIII. This did not prevent the Franciscans from establishing a permanent mission, and the order of St. Francis in turn pressed the Holy See to lift the monopoly. In 1597 the dispute was still raging in Rome and Madrid, where officials of the two orders staunchly defended their conflicting interpretation of the papal decisions (Pérez, 1922b: 476-478). On the Japanese field, the conflict was aggravated by the appointment of a Jesuit, Pedro Martins, as bishop of Japan. Martins considered that the Pope's briefs unambiguously meant the Franciscans must leave the country. The Franciscan commissar heading the mission, Pedro Bautista, while presenting himself as a "respectful son" of the bishop in a letter written in 1596, had no intention to comply. He retorted that Pedro Martins had no mandate to interpret the pope's decisions (Pérez, 1916a: 249-250). Bautista even compiled a denunciation of all the attacks that the bishop conducted on the Franciscans. Pedro Martins in particular pronounced the excommunication of the Franciscans and of anyone who attended their churches to receive the sacraments. He also asked Christians, whether Japanese or Iberian, to abstain from supporting the Franciscans through almsgiving, which would effectively deprive them of their means of subsistence (Pérez, 1916b: 250-254).

The coexistence of missionary orders such as the Franciscans and the Jesuits was inherently difficult because their values, organization and methods stood completely at odds. ${ }^{4}$ However, tensions were usually averted thanks to the partitioning of colonial societies into exclusive preserves for the various orders, as was the case in Goa or the Americas (Xavier, 2008). Japan thus presented a rare case of unrestricted competition, aggravated, among other things, by the fact that the Jesuits did believe they should enjoy a monopoly on the country. This was a deep and bitter conflict and the chronicles of the martyrdom reflect that to varying degrees. Marcelo de Ribade- 
neira does claim that there were good relations with the Society of Jesus, or at least with some of its members (Ribadeneira, 1599: 468), but he goes on to expose the close links between the Jesuits and various Japanese enemies of the Franciscans, and in particular the governor of Nagasaki, who tried to prevent them from settling in the city (Ribadeneira, 1599: 467; 517). He makes no mention, however, of how the Franciscans themselves depended on the support of the Japanese authorities against the Jesuits, obtaining as they did from Hideyoshi the right to establish in their rivals' heartland in the south of the archipelago. While Jeronimo de Jesús (1925: 103) admits to that fact, he proves himself the most stringent critic of the Society of Jesus. One chapter of his chronicle is even entitled "of the bishop's coming to Japan and of the persecution that was levelled against the discalced friars of Saint Francis", putting the two events on an equal footing (De Jesús, 1925: 567). De Jesús claims he was not opposed to the sending of a bishop per se, but he decries that choosing a Jesuit for the position was bound to result in the unfair treatment of his order. But more importantly, the Jesuits feature prominently in the causes leading to the violence of 1597. Denying that the San Felipe incident in any way pushed Hideyoshi to take action ("No tiene fundamento", groundless), the chronicler accuses the bishop's open hostility to the Franciscans of having played into the hands of the Japanese. Jerónimo de Jesús chastises the Jesuits for compromising themselves in mercantile activities and colluding with the Japanese ruling elite, by focusing on the upper strata of society, dressing in fine silk and visiting Hideyoshi with much pomp. ${ }^{5}$ Moreover, while the Society did not dare to ask directly the Nagasaki authorities to expel the Franciscans, it pressured the Portuguese into making such a request (De Jesús, 1926: 405-406). It is thus hinted that the Jesuits took their plotting one step further and tried to have Hideyoshi eliminate the Franciscans physically. The scheming, devious Jesuits provide an ideal counterpoint to the Franciscan's immaculate perfection.

\section{AS A TESTIMONY OF THE FRANCISCANS' CHRISTIAN PERFECTION}

\section{A glorious setback}

The chroniclers' description of the event is geared towards the glorification of Franciscan action in Japan, against the idea that the persecutions decreed by Hideyoshi implied a rejection of their methods. "Persecution" is by the way somewhat misleading, as only missionaries were targeted, and no measures were taken against Christians in general. ${ }^{6}$ The Franciscan chroniclers intended to elevate what could otherwise be constructed as a relatively minor, if tragic setback in the evangelization of Japan, into a major triumph for their order.

Marcelo Ribadeneira provides the most detailed account of the martyrdom, from the arrest to the executions on the hills of Nagasaki. "Narrative" is probably a better word here, as the unfolding of the event is rearranged into an edifying drama, in the vein of the religious literature prevalent in 16th century Spain - in which martyrdom is a leitmotiv (Civil, 2001: 25-37). The Franciscans are not just the passive victims of an injustice, but the hardships they endure reveal them as "true" followers in a heathen land (Heullant-Donat and Castelnau-L'Estoile, 2010: 12). In fact, the narrative is not structured by the logic of the trial (i.e. testifying of the innocence of the accused). The framing is that of a major spiritual confrontation in the quest for the evangelization of Japan (Pierron, 2003: 15), and indeed, military vocabulary features prominently in the text (Ribadeneira, 1599: 476). The mission is constructed as a collective struggle against pagan might in which the Franciscans and their Christian converts were bound to triumph. The Franciscan "soldiers of Christ" lose the physical battle only to win decisively on the spiritual front (Ribadeneira, 1599: 478). The battle is even presented as a divine grace, rather than as a display of heroism. Indeed, Ribadeneira (1599: 506) stresses that only a few Franciscans were condemned to death: other disciples failed to be granted that "privilege", despite trying to join the procession of the convicts. The narrative turns a relatively isolated incident into a collective triumph, but in which the unworthy Jesuits could not share, because of their inappropriate methods, as de Jesús (1925: 563) points out:

Thus acted the discalced friars of San Francisco in Japan, and for that they earned the glorious crown of martyrdom, like those of the early Church etc. And the fathers of the Society, who had different methods, the Lord did not allow them to obtain this crown; the Lord wanting to show in this that those who only go down the path of Christian sincerity are rightful etc. ${ }^{7}$

The violence is exploited by way of a thorough dramatization of the martyrdom. Ribadeneira (1599: 421), who himself uses the word "spectacle", frames the scene of the crucifixion as the inevitable denouement of a play in several acts. The martyrdom is heralded by divine luminous signals: a white cross appears in the sky, foreshadowing the fate of the Franciscans (Ribadeneira, 1599: 461). But it is above all the suffering body that takes center stage, and well before the crucifixion (Crouzet, 1990). The arrest and the long journey from the capital Miyako to Nagasaki already allows for an extensive focus on the physical hardships. The execution itself invites the reader to experience the event, so to speak, in the flesh. The martyrs' final words suggest an otherworldly inspiration (Ribadeneira, 1599: 532-533). The joy they display until their last moments contrasts with the pathos of the description, a testimony to their detachment and to their anticipation of the bliss of the afterlife. But the episode also appears as a reenactment of the Passion in a pagan land, witnessed by Christians and heathens and a reassertion of the Christian message. In Tertullian's words, "semen est sanguis Christianorum" - the blood of the martyrs is the seed of the church: the chronicle's next chapter is devoted to the reception of the martyrdom by those who witnessed 
it. He mentions the devotion of the Japanese Christians, who are shown to be strengthened in their faith by the unwavering exhortations of the martyrs, but also of the Portuguese and Spanish, a significant presence in Nagasaki. In fact, although pagans certainly attended the event, they could only have been a minority: the city had become mostly Christian since the donation of the city to the Society of Jesus by daimyō Ōmura Sumitada, in 1580. ${ }^{8}$ The chronicler's angle on the event leaves in the shadow the actually disappointing effect the event had on conversions. ${ }^{9}$ But like many chroniclers, Ribadeneira was working to meet the expectations of a European public eager for canonical, edifying tales of martyrdom.

\section{Imitators of the early saints and of Christ himself}

This intention was not so much to thrill readers as to convince them that a miracle akin to the early Church's heydays had just taken place. Many explicit parallels with ancient Rome are found in the text: the young Japanese Church - a minority faith exposed to pagan power - is compared to the primitive Church, and the disciples of St. Francis, to the early Christian martyrs, such as St. Cyprian (Ribadeneira, 1599: 470; De Jesús, 1925: 563). Such classical references were hardly a novelty; indeed, not only were they commonplace in popular Christian literary genres such as the lives of saints, but they were also easily found in missionary discourse, including Jesuit rivals'. For instance, it was in this framework that the visitor to the West Indies, Alessandro Valignano, wrote of "persecutions" in 1582 to refer to the consequences of the instable political context. ${ }^{10}$ To him, the Society was enduring spiritual hardships which would strengthen it and make it more effective at converting the Japanese (Valignano, 1990: 215). But the Franciscans could put the focus on the physical dimension of their persecution, which conveyed much more symbolic force. It allowed them to suggest that the "persecution" they endured in Japan was not only authentic, but a resurgence of the earliest (hence purest) forms of persecutions. The Jesuits' negation of the martyrdom could then be equated to a questioning of the Church's most sacred historical figures. As Eric Suire (2001: 35) suggests, it is the conformity of a saint to the tradition which warrants the martyrdom's authenticity.

But the Franciscans went further, by presenting the martyrs as living portraits of Christ himself. ${ }^{11}$ De Jesús (1925: 570) points out that, just like Christ, the order was looking after the poor above all. The martyrs themselves seem to identify to him, since they ask to be crucified on a Friday (the favor, however, was denied) (De Jesús, 1925: 518). But it is obviously the mode of execution which makes way for an easy parallel: Hideyoshi decided to have them crucified, a common form of punishment in Japan, generally employed against robbers. ${ }^{12}$ Accordingly, the chroniclers suggest an analogy between the Stations of the Cross and the torments inflicted on the missionaries on their way to the execution. For instance, the authorities had the ears of the Franciscans cut off, and the blood covering their face is explicitly compared to that of Christ (from the crown of thorns) by Ribadeneira (1599: 489490). In fact, he devotes an entire chapter to the imitatio Christi theme, which follows the chapter narrating the execution. To the chronicler, the geographic situation of the martyrdom - a dry hill over Nagasaki - also recalls the location where Christ was murdered. Just like him, the Franciscans did not resist their arrest, endured a passion, and kept on spreading God's word until the very end (Ribadeneira, 1599: 537-545).

Following Thomas Aquinas' scholastics, which asserted that the value of martyrdom lay in the imitation of Christ, the chroniclers worked as self-styled hagiographers to demonstrate the perfection of the lives and deaths of the martyrs (Suire, 2001: 154). Their martyrdom seems all the more exceptional as there had been few recent instances in Europe (Gregory, 2001), and crucifixions in particular were unheard of. But all the while, they chroniclers were also promoting the ancient model of sainthood, which was favored by the Franciscans, as well as showing that the martyrs had closely followed the founding principles of the order. The virtues assigned to poverty and humility in particular are constantly highlighted throughout their writings, with a focus on their work with the poor and lepers (De Jesús, 1925: 561). Sainthood is closely associated with the observance of the Rule in Franciscan thinking; in the words of André Vauchez (1988: 395-396), "it is not only an ideal to be commended as a source of inspiration. It constitutes a true norm of perfection, and only those who follow it stringently may one day hope to share in the glory of the Founder". To the chroniclers, the 1597 martyrs were not only living images of Christ, but through their lives a perfect exemplification of the next highest norm, namely the sainthood of Francis of Assisi (De Jesús, 1925: 571).

This inseparably Christ-like and Franciscan triumph naturally paves the way for a vindication of the order's methods against the policies of their Jesuit rivals. Jerónimo de Jesús indeed denounces the latter's opposite choice of focusing on the upper tiers of society:

The company looked for the leaders, because by winning the great, they win their vassals; although by losing the Great, they lose their vassals, as experience has shown. [...] The Holy Commissar [Pedro Bautista], on the contrary, sought the poor and gave to the poor, remembering what Christ our Lord said, that his Eternal Father sent him to preach to the poor: Pauperibus evangelizare misit me Dominus.

As a result of their dedication to the poor, the conversions obtained by the Franciscans are authentic and sincere:

The company wanted to be the largest in Japan and around the world and to obtain the conversion of Japan by way of its prudence, wealth, commerce and goods; and conversely, the holy Commissioner, as so true son of St. Francis, a follower of the highest evangelical poverty, wished to obtain the conversion of Japan but through God only, and wanted and desired to show how souls could be converted without wealth. 
The references to St. Francis and to evangelical poverty are as many ways of asserting the distinctive identity of the Franciscan mission to Japan, against its Jesuit competitor. The martyrdom of 1597 appears as divine sanction of the mendicant orders' methods. For the chroniclers, there could be no question as to the holiness of the martyrs. They wasted no time in asking the pope for their recognition - the request was made the same year - and to encourage their worship in Japan and beyond. In a very small lapse of time, the Franciscans managed to turn a local and relatively minor incident into a significant event for Christians across the world.

\section{A LOCAL INCIDENT WITH A WORLDWIDE REACH: THE RESONATING POWER OF THE MARTYRDOM}

\section{Regional ramifications}

Some Franciscans might have hoped that the martyrdom would bring a (victorious) end to their conflict with the Jesuits. In fact, their rivalry only worsened. More, it was compounded by a new trade dispute between the Portuguese and the Spanish in the region.

The difficult coexistence of the Iberians in the Far East began with the arrival of the Spanish in the Philippines, which breached the 1529 treaty of Zaragoza. Charles V had indeed pledged to renounce any claim on the Moluccas and accepted the antemeridian of the earlier Treaty of Tordesillas as a line of demarcation (Jacquelard, 2015). The union of the crowns from 1580 onwards did not end the tensions: while Philip II agreed, at the Cortès de Tomar, to preserve Portuguese interest and to keep the two empires separate, the Spanish in the Philippines constantly encroached on the Portuguese monopoly. While the Manila authorities had warned the Franciscans not to try and get a foothold in Japan, they backed them once this became a fait accompli, because their presence there could be diplomatically valuable (Vu Thanh, 2016). Meanwhile, the Jesuits had enjoyed from the start the full support of the Portuguese merchants - who were interested in the silk trade - and of the senate of Macau. The conflict between Franciscans and Jesuits was bound to coincide with the colliding Spanish and Portuguese interests in the region. The martyrdom reactivated the tensions, if only because of the accusations levelled by the Franciscans.

The new Jesuit bishop, Luís Cerqueira, who succeeded Pedro Martins in 1598, proved even more combative (Costa, 1998). He immediately set out to convince the Philippine authorities of the disastrous consequences of their rivals' behavior in Japan. Cerqueira's letter to the governor of Manila begins with an evocation of the martyrdom of $1597 .{ }^{13}$ To him, the Franciscans pushed the Japanese leadership to action by their lack of restraint and their careless exposure to suspicions of spying. This amounted to severely questioning the authenticity of the martyrdom, since it implied that the victims had not really been targeted because of their beliefs but because they had challenged temporal power.
But the bishop also describes how Japanese Christianity suffered in the wake of the executions. First, he denies the Franciscan chroniclers' claim that the Jesuits, thanks to their supposed closeness to the Japanese leadership, were spared. He points out that several Jesuit churches and establishments, including the college of Amakusa, dedicating to the training of indigenous personnel, were destroyed on Hideyoshi's orders. It was only thanks to their role as negotiators with the Portuguese in Nagasaki that they escaped a worse fate. Cerqueria also laments that the Franciscans will not learn from their mistakes, as Jeronimo de Jesús, who narrowly escaped the persecution, returned to the country a few months later, and therefore risked provoking further action from the Japanese authorities. ${ }^{14}$ They are portrayed as reckless in addition to being disobedient to both the Pope and the King, for the reasons mentioned earlier. The bishop therefore asks the governor of Manila to monitor their movement and prevent them from going to Japan. ${ }^{15} \mathrm{He}$ adds that, because of the Franciscans, his predecessor had to leave the country so as not to raise the suspicion of the Japanese leadership, which resulted in his death in a shipwreck.

But the martyrdom also sent shockwaves among the lay Portuguese and Spaniards in the region. The Portuguese were alarmed that Hidyoshi might put an end to the trade with Macau, which would be a significant blow to the finances of the Estado da Índia (Subrahmanyam, 1999: 137). There were rumors that the administration of all their temporal and spiritual establishments between Malacca and Japan would be transferred to the Spanish in Manila. Macau, heavily reliant on the trade between Japan and China, would risk losing that resource. Cerqueira recognizes that it was not only the Franciscans who spread such rumors, but their intrusion had contributed to foster Portuguese distrust and resentment towards the Spanish.

Paradoxically, in their effort to deny the authenticity of the martyrdom, Cerqueira and the Society of Jesus probably contributed to magnify the event in the region. In any event, the Franciscans themselves were determined to bring it to much wider attention.

\section{A martyrdom of global relevance: towards beatification}

Not only were the Franciscans quick to spread the news of the martyrdom and to ask for the beatification of the crucified missionaries, but their efforts at constructing the event as an exemplary display of holiness seem to have been well received. The martyrdom quickly attracted considerable attention across the Catholic world. Besides boosting their mission's profile, the Franciscans were hoping to nip in the bud the Jesuit's opposition to the beatification, and more generally, to silence for good their claim to a monopoly on Japan. A new battle for influence began, pitting the two orders against each other in Europe, Asia and the Americas.

A long and uncertain process, the recognition of sainthood was an ideal breeding ground for a protracted strug- 
gle. Rome was, since the 12 th century, the only authority capable of awarding sainthood (Suire, 2001: 349-350). The decision warranted that a person's life was worthy of imitation and veneration. It consisted in a process based on the examination of written depositions reporting the hearings of witnesses. The process went through two stages. First, the bishop in whose jurisdiction the candidate died was to gather preliminary information during a first "informative" or "ordinary" process. The conclusions were then submitted to the Pope, who could decide to abandon the case or proceed to the second stage, in which case the testimonies were then scrutinized by a specialists" commission. This initiated the "curial" or "apostolic" process, which from 1588 onwards was the prerogative of the Sacred Congregation of Rites (Suire, 2001: 352). However, the faithful did not often wait for the process to be completed before taking to the worship of the potential saint. As Eric Suire explains, there is commonly a complete misunderstanding between the faithful and the Church. To the earlier, the canonization was (and still is) indeed often seen as the mere validation of an already established cult. The martyrdom of 1597 followed that pattern: the Franciscan chroniclers note that even before the missionaries had passed away, the faithful were collecting the relics-to-be, and in particular the blood dripping from their faces (Ribadeneira, 1599: 490). Ribadeneira and Jeronimo de Jesús use the word "martyr" before any official recognition has been granted (Ribadeneira, 1599: 485) - they were writing respectively in 1599 and 1600 , that is, well before the beatification ordered by Urban VIII in 1627 - yet they write as though the issue were beyond doubt. ${ }^{16}$ The idea of course was to convince the Holy See that the cult was already established and that it only needed to be made official (Suire, 2001: 327). This was a common strategy that was in no way specific to the order of St. Francis. What did make the situation rather unusual was that the strong opposition coming from another order.

While the Society of Jesus could not deny the fact of the crucifixions, it refused to use the word "martyr" and denied the recognition of any miracles that could be attributed to the victims. The Jesuit stance was that the Franciscans brought Hideyoshi's violence on themselves by refusing to behave with discretion in spite of the warning embodied by the edict of 1587 . The ultimate cause of the incident thus lied with the Franciscans' insubordination to temporal power (Pérez, 1921d: 168). ${ }^{17}$ As for the miracles, without which there can be no sainthood, bishop Cerqueira saw them as little more than a manipulation on behalf of several Franciscan chroniclers, as his letter to the Franciscan provincial suggests: for him, the miracles reported for instance by Juan de Santa Maria in a memoire in 1599 are simply false. ${ }^{18}$ Cerqueira reaffirmed this claim in a letter to the King in 1605, in which he deplores that the spread of false reports in Asia, America and Europe, to the detriment of the Japanese mission. ${ }^{19}$ Indeed, the Franciscans largely ignored such objections and wasted no time in circulating descriptions of miracles that followed the executions. One Relación de algunos casos que suzedieron después de aver sido crucificados y muertos los sagrados en Japon mentions on March 14, 1597 - less than one month after the event - the presence of columns of fire in the sky above the site of the executions (Pérez, 1921c: 86). Ribadeneira (1599: 545), for his part, asserts that the bodies of the missionaries were incorrupt, a traditional sign of holiness. Moreover, the Franciscans claimed to have received the approval of the bishop Pedro Martins, which was a necessary first step. Unsurprisingly, Cerqueira disputed this (Pérez, 1921e: 216-217). ${ }^{20}$

The Franciscans were thus quick to assemble all the necessary evidence for the process, with the backing of the administrative and religious authorities in Manila. As early as 1597 , the colony's Franciscan commissar compiled the testimonies of some fifteen witnesses. The majority of them were residents of the Philippines, but the group included the captain of the San Felipe as well as a few Japanese who attended the executions (Pérez, 1923a: 160). They give an account of the event that they witnessed or heard about as well as of the miracles that ensued. They also mention the presence of several Jesuits at the executions. The reports, however, are not in free form. They are the produce of closed and strongly suggestive questions. The question about a possible presence of the Jesuits, and of the bishop himself, obviously aimed at implying Jesuit recognition of the martyrdom. But the Franciscans mobilized support not only in the Philippines, but also in America. Their representative for New Spain, Friar Matías de Gamarra, mentions receiving a document from the bishop of China, Dom Leonardo de Saa, drafted at the request of the Franciscans in Macau and certifying of the authenticity of the various testimonies produced by members of the order. The Franciscan networks mobilized across the globe to support the beatification, which would, it was hoped, reflect positively on the whole order. The authorities of New Spain and Asia were all the more interested in the undertaking as one of the victims of 1597, Gonzalo Garcia, was born in Baçaim (Vasai) in India, and most of the Japanese staff had previously worked in America. As for Felipe de Jesús, who was born in Mexico City, his martyrdom would make him the very first Mexican saint and later the patron saint of city (Durán, 2006 and Conover, 2011). ${ }^{21}$ The cult of the martyrs rapidly spread throughout Catholic Asia and America, helped by the circulation of the numerous relics collected in 1597 (Pérez, 1921d: 196-197). The friars who escaped execution, however, failed in their effort to send the bodies to the Philippines: according to Augustín Rodriguez, the Society of Jesus prevented them from doing so (Pérez, 1921a: 197). Chronicler Paulo da Trindade (1967: 558), writing some time later, qualifies this accusation. He indicates that Hideyoshi allowed ambassadors from the Philippines to collect the bodies, but the Spanish and Portuguese staying in Japan, well aware of the reputation of the martyrs, had already collect so much material that little was left (part of it however made it to Spain, after transiting through Manila: the relics ended in the possession of the San Francisco convents in Salamanca and Se- 
ville) (Castelnau-L'Estoile, 2009: 754). The cult also spread to non-Spanish territories, under the action of Portuguese friars. Martin de la Ascensión's head was thus held at the San Francisco convent of Goa, while Gonçalo Garcia's arm was given to that of Chaul (Trindade, 1967: 559). The enthusiasm for the emergence of a properly Asian sainthood, visible in the effort to keep the relics in the continent rather than sending them back to Europe, suggests a significant degree of spiritual integration in Asia, in spite of the scattered nature of the Iberian presence and of the recurring rivalries (Županov, 2012).

The martyrdom of 1597 was shrouded in considerable ambiguity, a fact the Franciscan chronicles themselves did not quite conceal. It was largely provoked by the attitude of the missionaries, which in principle should have ruled out its recognition. The Franciscan chroniclers developed literary strategies to elide their responsibilities and instead put the blame on the Society of Jesus, to the point of mitigating the responsibility of the Japanese authorities. This was part of a wider struggle, pitting the two orders against each other across three continents over the recognition of the martyrdom, the respective value of the two orders' evangelical methods, and, ultimately, over the legitimacy of the Franciscan presence is Japan. It resulted in a clear victory for the order of St. Francis: the mission gained considerable publicity and the order as a whole benefited from the recognition obtained first from the faithful, later from the Holy See. The Jesuits' hopes of convincing Rome and Madrid to order their rivals to leave Japan were effectively dashed. Meanwhile, the ease with which the Franciscans saw the cult of the martyrs spread in Asia testifies of the spiritual integration of the European presence across the continent. The conflict between the Franciscans and the Jesuits, however, continued. It would only be settled by the Japanese authorities in 1614, with an outright ban on Christianity that would be strictly enforced up until the 19th century.

\section{NOTES}

126 men, European and Japanese alike, were executed in 1597 on the hills of Nagasaki: six Franciscans, 17 lay tertiary Franciscans and three Jesuits.

2 The accounts of the 1597 martyrdom are too many to be cited here. Many were written in the 19th century, as the martyrs were canonized by Pius IX in 1862 . This article relies mostly on the accounts of two Franciscan who were members of the Japanese mission at the time of the persecutions and as such were key witnesses of the event: Marcelo de Ribadeneira and Jeronimo de Jesús. See Pérez (1923b: 507-544).

3 The Ikkō (Jōdo Shinshū) sect was founded in 1224 by the monk Shiren. During the sengoku-jidai period, it built its own army of warrior monks.

4 The Jesuits also came into conflict with the Dominicans and the Augustines, who established themselves in Japan soon after the Franciscans, albeit in even small numbers. On the Dominicans in Japan, see Aduarte (1962) and Orfanel (1633).

5 On the implication of the Jesuits in the silk trade, see Cooper (1972: 423-433).

6 Ribadeneira himself admits to that fact, but he uses the word "persecution" nonetheless.

7 For his part, Ribadeneira mocks the Jesuits' envy at the Franciscan martyrdom. See Ribadeneira (1599: 470).
8 The Jesuits effectively ruled the city from 1580 to 1587 , when it passed under the control of governors appointed by Hideyoshi. See Elison (1988).

9 I have yet to find missionary sources attributing a single conversion to the impression created by the martyrs.

10 The Jesuit mission was established in a context where central authority was yet inexistent. They had to build alliances with local daimyōs who were caught in constant warfare and intrigue, which resulted in frequent changes of fortune for the Society.

11 The theme of the imitatio Christi was not a novelty either, since it dates back to medieval times. See Vauchez (1988: 518).

12 The mode of execution however differed from the ancient Western model in that the victims died by spearing, and not by suffocation.

13 Letter by Luís Cerqueira to the governor of the Philippines, written in Nagasaki, 1 October 1598, in Archivum Romanum Societatis Iesu, Rome [ARSI], Japsin 13 I, f. 164.

14 Ibid., f. 164v.

15 Ibid., f. 165.

16 The Holy See proceeded with the canonization in 1862, which resulted in the production of more lives of saints.

17 The Franciscan testimonies dispute this: they mention a public notice explaining that the crucifixion was ordered by Hideyoshi as a punishment for preaching the law of God.

18 Letter by Luís Cerqueira to the provincial for the Franciscans, Nagasaki, 17 October 1601, in ARSI, Japsin 20 I, f. 109v.

19 Letter by Luís Cerqueira to the King, Nagasaki, 5 March 1605, in ARSI, Japsin 21, f. 6v.

20 This is actually a Spanish translation of a Portuguese document attributed to the bishop. I have not yet come across the original, but the discourse lent to Cerqueira is consistent with other letters at our disposal, where the bishop and his predecessor castigate the Franciscans and the martyrdom.

21 The martyrdom of 1597 is also depicted by a large mural which was painted in the 18th century in the cathedral of Cuernavaca (Mexico).

\section{REFERENCES}

Aduarte, Diego de (1962) Historia de la Provincia del Santo Rosario de la Orden de Predicadorens en Filipinas, Japón y China. Consejo Superior de Investigaciones Científicas, Madrid.

Barreto Xavier, Ângela (2008), A invenção de Goa: poder imperial e conversões cuturais nos séculos XVI e XVII. ICS, Lisbon.

Bourdon, Léon (1993) La Compagnie de Jésus et le Japon. Calouste Gulbenkian Fundation, Paris, Lisboa.

Boxer, Charles Ralph (1951) The Christian Century in Japan 15491650. University of California Press, Berkeley.

Brockey, Liam Matthew, (2016) "Conquest of Memory: Francican Chronicles of the East Asian Church in the Early Modern Period", Culture \& History Digital Journal, 5 (2): e015. doi: http://dx.doi.org/10.3989/chdj.2016.015. [accessed 27/November/2016].

Castelnau-L'Estoile, Charlotte (2009) «Le partage des reliques. Tupinamba et jésuites face aux os d'un missionnaire chaman (Brésil, début du XVII ${ }^{\mathrm{e}}$ siècle)». In Reliques modernes. Cultes et usages chrétiens des corps saint des Réformes aux révolutions, vol. 2, edited by Boutry, Philippe; Fabre, Pierre-Antoine and Julia, Dominique. EHESS, Paris: 751-775.

Civil, Pierre (2001) «Les martyrs de la foi dans l'Espagne de la Contre-Réforme. Textes et images». In Ecriture, pouvoir et société en Espagne aux XVI et XVII siècle. Hommage du CRES à Augustin Redondo, edited by Civil, Pierre. Publications de la Sorbonne/Presses de la Sorbonne Nouvelle, Paris: 25-37.

Conover, Cornelius and Cory (2011) "Saintly Biography and the Cult of San Felipe de Jesús in Mexico City, 1597-1697". The Americas, 67 (4): 441-466.

Cooper, Michael (1972) "The Mechanics of the Macao-Nagasaki Silk Trade". Monumenta Nipponica, 27: 423-433.

Costa, João Paulo Oliveira e (1998) O cristianismo no Japão e o episcopado de D. Luis Cerqueira. PhD dissertation, Lisboa. 
Crouzet, Denis (1990) «Imaginaire du corps et violence aux temps des troubles de religion». In Le corps à la Renaissance. Actes du XXX colloque de Tours 1987, edited by Céard, Jean; Fontaine, Marie-Madeleine and Margolin, Jean-Claude. Aux Amateurs de livres, Paris.

De Jesús, Jerónimo (1925) «Relación del glorioso martirio de seis frayles Descalços de san Francisco y veinte Japones». Archivum Franciscanum Historicum, 18: 90-113; 559-584.

De Jesús, Jerónimo (1926) «Relación del glorioso martirio de seis frayles Descalços de san Francisco y veinte Japones». Archivum Franciscanum Historicum, 19: 385-417.

Durán, Norma (2006), "La retórica del martirio y la formación del yo sufriente en la vida de San Felipe de Jesús". Historia y Grafia, 26: 77-107.

Elison, George (1988) Deus Destroyed, the Image of Christianity in Early Modern Japan. Harvard University Press, Cambridge MA.

Gil, Juan (1991) Hidalgos y samurái. España y Japón en los siglos XVI y XVII. Alianza, Madrid.

Gregory, Brad S. (2001) Salvation at Stake. Christian Martyrdom in Early Modern Europe. Harvard University Press, Cambridge (MA),London.

Hall, John Whitney (editor) (1991), The Cambridge History of Japan, vol. 4, Early Modern Japan. Cambridge University Press, New York.

Heullant-Donat, Isabelle and Castelnau-L'Estoile, Charlotte (2010) "Introduction". In Le martyr(e). Moyen Âge, Temps Modernes, edited by Bélissa, Marc and Cottret, Monique. Kimé, Paris.

Jacquelard, Clotilde (2015) De Séville à Manille, les Espagnols en mer de Chine. Les Indes savantes, Paris.

Orfanel, Jacinto (1633) Historia eclesiástica de los sucesos de la christandad de Japón desde el año de 1602 que entro en el la Orden de Predicadores hasta el de 1620. Alonso Martin, Madrid.

Pérez, Lorenzo (editor) (1916a) "Letter of Pedro Bautista to Bishop Pedro Martins, 1596". Archivo Ibero-Americano, 6: 249-250.

Pérez, Lorenzo (editor) (1916b) "Información, October 4, 1596". Archivo Ibero-Americano, 6: 250-254.

Pérez, Lorenzo (editor) (1921a) "Letter by P. Agustín Rodríguez to P. Agustín de Tordesillas, Nagasaki, March 14, 1597'. Archivo Ibero-Americano, 15: 196-197.

Pérez, Lorenzo (editor) (1921b) " Relación del biaje del galeon San Phelipe de Su Magestad; arribada que hiço al Japon y su pérdida y lo que más á succedio. Año 1596". Archivo Ibero-Americano, 16: 55-74.

Pérez, Lorenzo (editor) (1921c) "Relación de algunos casos que sucedieron después de aver sido crucificados y muertos los sagrados en Japón, por los quales se deven dar a nuestro Señor muchas gracias". Archivo Ibero-Americano, 16: 86-88.

Pérez, Lorenzo (editor) (1921d) "Información de pedimento del Comissario de los Descalços de las Philippinas ante el Arçobispo dellas, en 25 de Junio de 1598; digo, ante el cabildo, sede vacante, año 97, de la embaxada y causa del martirio". Archivo Ibero-Americano, 16: 163-215.
Pérez, Lorenzo (editor) (1921e) "Certificación de Pedro Martins, obispo de Japón”. Archivo Ibero-Americano, 16: 215-218.

Pérez, Lorenzo (editor) (1922a) "Información a pedimento del Provincial descalzo de Philippinas ante el Arçobispo de Manila, 15 junio 98". Archivo Ibero-Americano, 17: 31-39.

Pérez, Lorenzo (editor) (1922b) "Memorial del Padre Francisco de Montilla". Archivum Franciscanum Historicum, 15: 476-507.

Pérez, Lorenzo (editor) (1923a) "Información de pedimento del P. Custodio de San Francisco de Mallaca y China ante el Obispo de la China, en 2 de Junio de 97. Del martirió y causas del". Archivo Ibero-Americano, 19: 160-185.

Pérez, Lorenzo (1923b) "Fr. Jerónimo de Jesús, restaurador de las misiones del Japón, sus cartas y relaciones". Archivum Franciscanum Historicum, 16: 507-544.

Pierron, Jean-Philippe (2003) «La dimension figurative du témoignage. L'exemple des premiers martyrs chrétiens». Revue des sciences humaines, 269 : 15-32.

Ribadeneira, Marcelo de (1599) Historia de las islas del archipiélagos y reinos de la gran China, Sian, Cuchinchina, y Jappon y de lo sucedido en ellos a los religiosos descalcos de la orden del san Francisco. Nicolas Mucio, Roma.

Subrahmanyam, Sanjay (1999) L'Empire portugais d'Asie, 15001700. Maisonneuve et Larose, Paris.

Suire, Eric (2001) La Sainteté française de la Réforme catholique (XVI ${ }^{e}-X V I I^{e}$ siècles). Presses universitaires de Bordeaux, Pessac.

Tremml, Birgit (2016) "Friend of Foe? Intercultural Diplomacy between Momoyama Japan and the Spanish Philippines in the 1590". In Silver and Samurai: Maritime East Asia in Global History, 1550-1700, edited by Andrade, Tonio and Hang, Xing. University of Hawai'i Press, Honolulu: 65-85.

Trindade, Paulo da (1967) Conquista espiritual do Oriente, ed. Fernando Félix Lopes, 3 vols. Centro de Estudos Históricos Ultramarinos, Lisboa.

Valignano, Alessandro (1990) Les Jésuites au Japon. Translated by J. Bésineau. Desclée de Brouwer, Paris.

Vauchez, André (1988) La Sainteté en Occident aux derniers siècles du Moyen Âge. Ecole Française de Rome, Roma.

$\mathrm{Vu}$ Thanh, Hélène (2014) «Les liens complexes entre missionnaires et marchands ibériques: deux modèles de présence au Japon (1543-1639)». Le Verger, 5. http://cornucopia16.com/ blog/2014/09/08/helene-vu-thanh-les-liens-complexes-entremissionnaires-et-marchands-iberiques-deux-modeles-de-presence-au-japon-1549-1639/. [accessed 15/February/2016]

Vu Thanh, Hélène (2015) "Diplomates et missionnaires ? Le rôle des franciscains entre les Philippines et le Japon (1584-1597)". Études franciscaines, 8: 55-73.

Vu Thanh, Hélène (2016) "The Role of the Franciscans in the Establishment of Diplomatic Relations between the Philippines and Japan: trans-Pacific Geopolitics? (16th-17th centuries)". Itinerario, 40: 239-256.

Županov, Ines G. (2012) "Passage to India: Jesuit Spiritual Economy between Martyrdom and Profit in the Seventeenth Century". Journal of Early Modern History, 16: 121-159. 